EPRA International Journal of Economic and Business Review-Peer Reviewed Journal

Volume - 9, Issue - 4, April 2021 | e-ISSN: 2347 - 9671| p- ISSN: 2349 - 0187

\title{
IMPROVING THE DATABASE OF TOURISM SATELLITE ACCOUNTS IN UZBEKISTAN
}

\author{
Mamadjanov Abrorali \\ Ashiralievich $^{1}$ \\ ${ }^{1}$ Researcher at Tashkent State University of \\ Economics
}

The article describes the specifics of the database of tourism statistics of Uzbekistan, its compliance with the recommendations of international organizations and issues of its improvement.

KEYWORDS: tourist, excursionist, tourism statistics, national accounting system, tourism satellite account (TSA), observation, survey, accommodation facilities.

\section{DISCUSSION}

It is necessary to have complete statistics on the state of the industry in the country and its contribution to the country's economy, and it is also important to compare these figures with other countries, to form a system of modern measures to support the tourism industry. In this regard, it is advisable to use the standards developed by authoritative international organizations and the experience of foreign countries in the formation of a database of satellite accounting in tourism statistics and their use in the formation of industry statistics.

The directions of the formation of statistical indicators of the development of the tourism industry are described in detail in the manuals "International
Recommendations for Tourism Statistics 2008", "Tourism Satellite Account: Recommended Methodological Framework 2008", developed by the United Nations, World Tourism Organization (WTO), Organization for Economic Cooperation and Development (OECD), Eurostat.

In these manuals, the volume of tourist flows and information on tourist expenses, which are important in the formation of TSE tables, are collected and formed by the following methods $[3,4,5,6]$ : 


\section{Method of collecting data through the border registration system}

\section{Method of collecting data through the statistical reporting system of residential buildings}

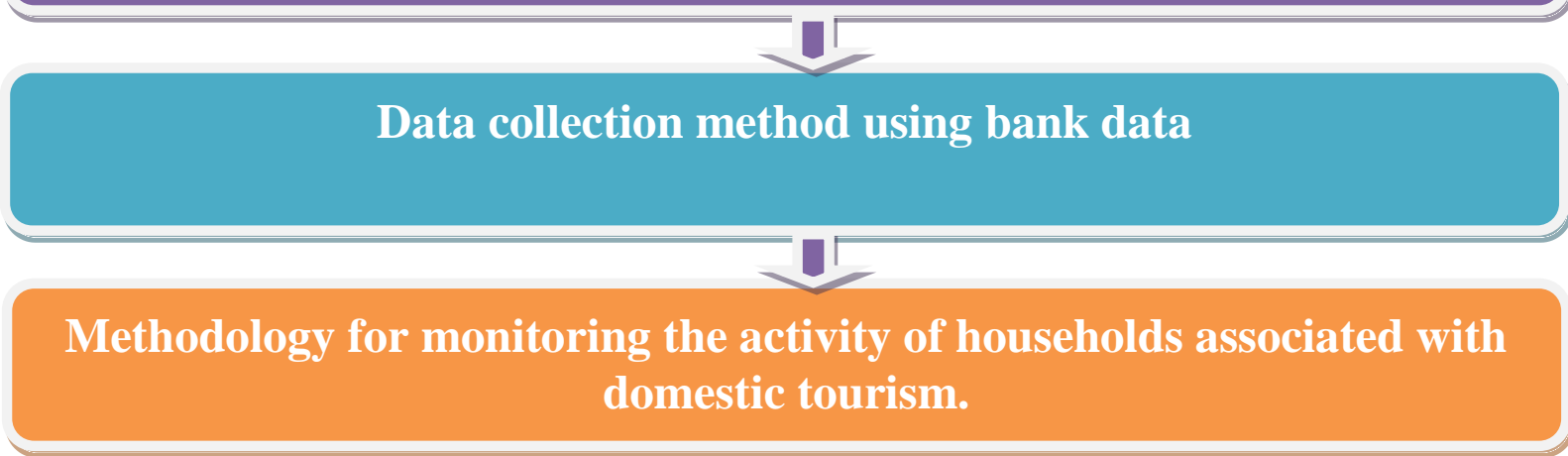

Figure 1. Methods for generating tourism statistics ${ }^{1}$

\section{Method of collecting data through the border registration system}

The method of collecting data through the border registration system is carried out at airports, railway stations, seaports, border posts and other places through immigration checkpoints at the entrance and exit from the country. The main sources of information about tourists are special questionnaires, entry (exit) cards, as well as foreign passports and visas.

The border check-in method is used in many countries. Some of them have established close bilateral cooperation in the area of border statistics. Canada collects information about its citizens returning from the United States and submits this information to the US National Tourism Administration. The border check-in method is used not only in the USA and Canada, but also in the UK, Spain, Cyprus, Portugal, Australia, Singapore, Turkey, Poland, Hungary, Bulgaria and many other countries around the world [2].

According to the State Statistics Committee, in 2019, Uzbekistan was visited by 6.7 million foreigners, which is $26.2 \%$ more than in $2018.92 .8 \%$ of all visitors are from the CIS countries, $7.2 \%$ are from non-CIS countries. In 2019, the number of visitors from non-CIS countries increased by $49.9 \%$ compared to 2018 .

${ }^{1}$ Developed by the author based on the recommendations of international organizations.
Entry (exit) cards used for registration at the border do not contain detailed information about places visited by tourists, periods of stay, residence, therefore, in addition, special observations are required when forming TSA tables.

The method of collecting data through special surveys is carried out by conducting a survey of visitors to the country. Surveys are usually organized in the form of a questionnaire. The data obtained (systematized and processed) during the survey will allow a detailed study of some aspects of tourism activities.

This method is widely used in the formation of TSA data in Uzbekistan. The main purpose of the survey was to assess the tourism costs of tourists visiting Uzbekistan and citizens of Uzbekistan leaving Uzbekistan for foreign countries. These surveys were carried out at airports, railway stations and main border checkpoints. The last such survey was conducted in Uzbekistan in 2018, during which 10,249 visitors were interviewed. Of these, 5,754 people are foreign citizens visiting Uzbekistan, and 4,495 are citizens of Uzbekistan visiting foreign countries. To reduce the error in summing up the survey results, the tourists were divided into visitors from neighboring countries, the CIS countries and the Far East, depending on the country of visit. Thus, their average cost was differentiated.

The results of this observation are currently being used to classify the domestic expenditures of foreign tourists in TSA Table 1 and the expenditures 
of Uzbek citizens visiting foreign countries in TSA Table 3 , in terms of goods and services by tourists and excursionists.

The following table presents data on the consumption of inbound tourism in the Republic of
Uzbekistan in 2019 by types of products and categories of visitors (Table 1 of the TSA), formed in this way (Table 1).

Table 1

Inbound tourism expenditure by products and classes of visitors for 20191

\begin{tabular}{|c|c|c|c|}
\hline & $\begin{array}{l}\text { Tourists (overnight } \\
\text { visitors) (1.1) }\end{array}$ & $\begin{array}{c}\text { Excursionists } \\
\text { (same-day } \\
\text { visitors) (1.2) }\end{array}$ & $\begin{array}{c}\text { Visitors } \\
(1.3)= \\
(1.1)+(1.2)\end{array}$ \\
\hline A. Consumption products & 10590374,1 & 50138,4 & 10640512,5 \\
\hline A.1 Tourism characteristic products & 7731890,2 & 7169,6 & 7739059,8 \\
\hline $\begin{array}{l}\text { 1. Accommodation services for } \\
\text { visitors }\end{array}$ & 2779738,1 & $\mathrm{x}$ & 2779738,1 \\
\hline $\begin{array}{l}\text { 2. Food-and beverage-serving } \\
\text { services }\end{array}$ & 289106,7 & 255,5 & 289362,2 \\
\hline $\begin{array}{l}\text { 3. Railway passenger transport } \\
\text { services }\end{array}$ & 85190,3 & 242,1 & 85432,4 \\
\hline 4. Road passenger transport services & 1385007,5 & 2568,7 & 1387576,2 \\
\hline 5. Air passenger transport services & 2573266,3 & 4059,4 & 2577325,7 \\
\hline $\begin{array}{l}\text { 6. Transport equipment rental } \\
\text { services }\end{array}$ & 188019,4 & - & 188019,4 \\
\hline $\begin{array}{l}\text { 7. Travel agencies and other } \\
\text { reservation services }\end{array}$ & 389467,1 & 42,1 & 389509,2 \\
\hline 8. Cultural services & 12455,6 & 0,6 & 12456,2 \\
\hline 9. Sports and recreational services & 29639,1 & 1,2 & 29640,3 \\
\hline A.2. Other consumption products & 2858483,9 & 42968,8 & 2901452,7 \\
\hline B. Other products & 990737,9 & 8005,9 & 998743,7 \\
\hline Total & 11581112,0 & 58144,3 & 11639256,2 \\
\hline
\end{tabular}

${ }^{1}$ Data of the State Committee on Statistics of the Republic of Uzbekistan.

According to the table, the consumption of visitors to Uzbekistan in 2019 will reach 11.639.3 billion soums, of which $99.5 \%$ went to tourists and $0.5 \%$ to excursionists. In addition, $66.5 \%$ of the total consumption of visitors was accounted for by ordinary travel products, $33.5 \%$ - by other products, the largest share of which were accommodation services $(23.9 \%)$, air passenger services $(22.1 \%)$ and consumption of services of ground passenger transport. (11.9\%).

In the method of collecting data through the statistical reporting system of residential buildings, statistical data on the number of visitors to residential buildings are formed by registering visitors to residential buildings. This method does not take into account tourists living in places of residence other than public ones (in the houses of relatives and friends, private accommodation), but there may be problems with the double entry of tourists into several public places during the trip.

The data collected in the course of statistical surveys of hotels and other accommodation facilities makes it possible to assess the distribution of visitors across the country, to identify the need for foreign and domestic tourists to choose the type of accommodation, and also to control the workload of the hotel base.

This method of statistical observation (registration of visitors to residential buildings) is used in Germany, Switzerland, Spain, Morocco, Tunisia, Nigeria, Senegal, Tanzania and other countries [2].

In the statistical practice of Uzbekistan, statistical accounting of residential properties is carried out on the basis of state statistical reporting provided once a year by legal entities providing tourist excursions and accommodation (means of 
collective accommodation). This statistical reporting includes Report on the service and accommodation of visitors (1-turism shakli) and Report on the service and accommodation of visitors from microcompanies and small enterprises (1-kb tur shakli) [7].

According to the State Statistical Report of the Republic of Uzbekistan, only $22.5 \%$ of tourists who visited Uzbekistan in 2019 were registered in public accommodation facilities. Of these, $5.2 \%$ in travel agencies and organizations, $16.2 \%$ in hotels and similar accommodation facilities, $0.5 \%$ in specialized accommodation facilities, $0.4 \%$ in individual accommodation facilities and $0.3 \%$ in other accommodation facilities. These data suggest that the data collected in this way does not fully reflect the number of inbound tourism visitors.

Also, this method does not take into account one-day visitors (excursionists) in statistical observations. Locals who visit hotels are also often not included in the observations. In developed countries, people who are tired of leading a regular lifestyle often visit hotels to change their lifestyle. In addition, it is impossible to collect relevant statistical reports for all residential buildings. In many countries, boarding houses, furnished rooms, private apartments and other accommodation facilities are not monitored, or tourists who change housing during a visit are counted twice.

International practice also uses the method of monitoring indicators of travel expenses based on data collection method using bank data. The tracking method based on bank data is carried out by collecting information about foreign exchange transactions carried out by tourists.

The central bank collects data on tourism spending through commercial banks and currency exchange offices. Bank tracking is used in France and other countries. Its widespread use has several advantages. It does not require additional information from tourists and does not complicate border formalities and the work of statistical offices. The data is processed by the central bank when compiling the balance of payments.

Regular and quickly systematized data allows you to analyze the dynamics of tourism costs and track their change. Thanks to well-organized settlements and strict control over the foreign exchange and financial markets, the observation method based on bank data allows a relatively reliable assessment of the value of travel expenses.

In countries with informal foreign exchange markets, the fact that some foreign exchange flows do not pass through the bank, that direct tourist payments are not taken into account, and that foreign tourists enter the country with local currency, distorts tourism expenditure data.

Also, this method does not allow displaying data in a breakdown, since accounting is based on the currency used by tourists.

In Uzbekistan, balance of payments data is widely used in the formation of TSA tables and in the process of comparative analysis of data.

Methodology for monitoring the activity of households associated with domestic tourism is also widely used in world practice. Table 2 TSA of Uzbekistan was formed on the basis of household data "Survey of domestic tourism and physical activity of the population", carried out using this method. This observation is carried out by the State Committee of the Republic of Uzbekistan on Statistics by conducting a survey of households in order to study tourist trips, related costs made by the population on the territory of the Republic of Uzbekistan [8].

The following table presents the information generated in this way on expenditures on domestic tourism by type of product and type of travel for 2019 (table 2).

Table 2

Domestic tourism expenditure by products, classes of visitors and types of trips, $2019^{1}$

(million soums)

\begin{tabular}{|l|c|c|c|}
\hline \multirow{2}{*}{} & \multicolumn{3}{|c|}{ Domestic tourism expenditure } \\
\cline { 2 - 4 } & Domestic trips & Outbound trips & \multirow{2}{*}{ All types of trips } \\
\hline A. Consumption products & $\mathbf{1 6 7 9 7 5 0 0 , 0}$ & $\mathbf{2 ~ 8 7 6 ~ 8 4 0 , 6}$ & $\mathbf{1 9 6 7 4 3 4 0 , 6}$ \\
\hline A.1 Tourism characteristic products & 7795600,0 & 2862844,5 & 10658444,5 \\
\hline 1. Accommodation services for visitors & 1122600,0 & 15,2 & 1122615,2 \\
\hline 2. Food-and beverage-serving services & 2515800,0 & 1657,3 & 2517457,3 \\
\hline 3. Railway passenger transport services & 237450,0 & 159692,1 & 397142,1 \\
\hline
\end{tabular}

\footnotetext{
${ }^{1}$ Data of the State Committee on Statistics of the Republic of Uzbekistan.
} 


\begin{tabular}{|l|c|c|c|}
\hline 4. Road passenger transport services & 3143900,0 & 548826,1 & 3692726,1 \\
\hline 5. Air passenger transport services & 42100,0 & 2152539,3 & 2194639,3 \\
\hline 6. Transport equipment rental services & 283850,0 & & 283850,0 \\
\hline $\begin{array}{l}\text { 7. Travel agencies and other reservation } \\
\text { services }\end{array}$ & 186000,0 & 114,4 & 186114,4 \\
\hline 8. Cultural services & 263900,0 & & 263900,0 \\
\hline 9. Sports and recreational services & 9001900,0 & 13996,1 & 9015896,1 \\
\hline A.2. Other consumption products & $\mathbf{2 5 9 2 \mathbf { 6 0 0 , 0 }}$ & $\mathbf{6 1 8 , 5}$ & $\mathbf{2 5 9 3 2 1 8 , 5}$ \\
\hline B. Other products & $\mathbf{1 9 3 9 0 \mathbf { 1 0 0 , 0 }}$ & $\mathbf{2 ~ 8 7 7 4 5 9 , 1}$ & $\mathbf{2 2 ~ 2 6 7 5 5 9 , 1}$ \\
\hline
\end{tabular}

The table shows that in 2019, expenditures on domestic tourism in Uzbekistan amounted to $22,267.6$ billion soums, of which $87.1 \%$ were for domestic tourism, and $12.9 \%$ were for domestic expenditures of citizens of Uzbekistan associated with foreign travel. Also, if you look at the data in the table by type of goods, the largest share falls on the purchase of consumer goods ( $40.5 \%)$, all types of transport services $(28.2 \%)$ and catering services $(11.8 \%)$.

In addition, administrative data statistics play a special role in the formation of the tourism satellite account. The administrative data of the respective organizations on the number of arrivals and departures by the flow of resident and nonresident visitors crossing the country's borders are used as administrative data in the formation of the tourism satellite account.

Information on the supply of tourism in Uzbekistan, which includes Table 5 of TSA, is formed on the basis of data from state statistical reports, such as "Report on services produced (provided) by type of economic activity" (1-xizmat shakli (annual)), "Report on the main indicators of the organization's economic activity" (1-korxona shakli (annual)), "Report of microfirms and small enterprises" ( $1 \mathrm{~kb}$ shakli (annual)), "Report on the activities of non-governmental non-profit organizations" (1-nnt shakli (annual)), "Report on the activities of non-profit organizations" (1-notijorat shakli (annual)) [8].

When generating information about the offer, data from hotels, travel agencies, tour operators, catering establishments, trade organizations, passenger transport companies (air, railway, water transport, etc.) and other organizations serving visitors are used.

Domestic supply for domestic tourism is the aggregate output of the tourism industry. The volume of intermediate consumption in the tourism sector is calculated on the basis of updated data on the costs of enterprises. The amount of value added created in the tourism industry is determined based on the difference between production and intermediate consumption in these industries.

Table 6, compiled in the Input and Output form, which is considered the most important of the TSA, provides an overview of production and consumption in the tourism and other sectors of the economy. The rows of the table show the types of products, in the columns - tourism and other sectors of the economy. The table also shows intermediate consumption at purchase prices.

The following table summarizes information on domestic supply and consumption of tourism in the country by sector collected using the above methods according to Table 6 of Uzbekistan's TSA for 2019 (Table 3).

Table 3

Total domestic supply and internal tourism consumption for $2019^{2}$

\begin{tabular}{|l|c|c|c|}
\hline & $\begin{array}{c}\text { Consumption } \\
\text { Internal offer, } \\
\text { million soums }\end{array}$ & $\begin{array}{c}\text { related to internal } \\
\text { tourism, million } \\
\text { soums }\end{array}$ & $\begin{array}{c}\text { Share of } \\
\text { tourism, \% }\end{array}$ \\
\hline A. Consumption products & $\mathbf{7 2 ~ 7 4 9 8 8 8 , 3}$ & $\mathbf{2 0 8 4 6 4 2 1 , 6}$ & $\mathbf{2 8 , 7}$ \\
\hline A.1 Tourism characteristic products & $\mathbf{3 8 0 8 6 3 1 8 , 4}$ & $\mathbf{1 8 3 9 7 5 0 4 , 3}$ & $\mathbf{4 8 , 3}$ \\
\hline 1. Accommodation services for visitors & 3930155,8 & 3902353,3 & 99,3 \\
\hline 2. Food-and beverage-serving services & 4544412,0 & 2806819,5 & 61,8 \\
\hline
\end{tabular}

${ }^{2}$ Data of the State Committee on Statistics of the Republic of Uzbekistan. 


\begin{tabular}{|l|c|c|c|}
\hline 3. Railway passenger transport services & 529837,8 & 482574,5 & 91,1 \\
\hline 4. Road passenger transport services & 18386598,4 & 5080302,4 & 27,6 \\
\hline 5. Air passenger transport services & 5962496,4 & 4771965,0 & 80,0 \\
\hline 6. Transport equipment rental services & 2274091,0 & 188019,4 & 8,3 \\
\hline $\begin{array}{l}\text { 7. Travel agencies and other reservation } \\
\text { services }\end{array}$ & 930431,2 & 673359,2 & 72,4 \\
\hline 8. Cultural services & 586597,7 & 198570,6 & 33,9 \\
\hline 9. Sports and recreational services & 941698,1 & 293540,3 & 31,2 \\
\hline A.2. Other consumption products & 34663569,9 & 2448917,3 & 7,1 \\
\hline B. Other products & $\mathbf{8 8 3 5 0 1 ~ 8 2 7 , 4}$ & $\mathbf{3 5 9 1 9 6 2 , 2}$ & $\mathbf{0 , 4}$ \\
\hline
\end{tabular}

The above table shows that in Uzbekistan $99.3 \%$ of services for the accommodation of visitors, $61.8 \%$ of catering services, $91.1 \%$ of railway passenger transport services, $27.6 \%$ of ground passenger transport services, $80.0 \%$ of air passenger services, $72.4 \%$ of travel agency services and other booking services, $33.9 \%$ of cultural services, $31.2 \%$ of sports and entertainment services, $8.3 \%$ of car rental services are consumed by tourists.

At the same time, Table 7 of the TSA reflects a quantitative assessment of employment in the field of tourism services in the tourism sector, as well as the number of enterprises employed and jobs in the tourism sector in the Republic of Uzbekistan. These data are formed on the basis of information from state statistical reports, such as "Labour Report" (1-mehnat shakli (annual)), "Report of microfirms and small enterprises" ( $1 \mathrm{~kb}$ shakli (annual)), "Report on the activities of non-governmental non-profit organizations" (1-nnt shakli (annual)), "Report on the activities of non-profit organizations" (1-notijorat shakli (annual)). Data on the number of enterprises working in the tourism sector are formed on the basis of data from the Unified State Register of Enterprises and Organizations [8].

The data on tourism gross fixed capital formation in TSA Table 8 show the total value of fixed assets acquired by manufacturers during the reporting period.

Indicators of gross fixed capital formation are formed on the basis of information from state statistical reports, such as "Report on investment activities, commissioning of buildings and structures" (1-invest shakli (annual)), "Report of microfirms and small enterprises" ( $1 \mathrm{~kb}$ shakli (annual)), "Report on the activities of non-governmental non-profit organizations" (1-nnt shakli (annual)), "Report on the activities of non-profit organizations" (1-notijorat shakli (annual)) [8].

According to the data on the total accumulation of fixed capital in the tourism sector of Uzbekistan (Table 8 TSA), formed on the basis of these sources in 2019, the total accumulation of fixed capital in the tourism sector amounted to $10,348.5$ billion soums. Of these, $56.3 \%$ are machinery and equipment, and $39.7 \%$ are buildings and structures. When analyzing tourism by sector, of these, $43.2 \%$ transport service providers, $30.4 \%$ - visitor accommodation service providers, $19.9 \%$ - sports and recreation service providers, and $4.1 \%$ - catering service providers.

Due to the lack of data sources for the formation of Table 9 TSA, these data are currently not generated in Uzbekistan.

The data sources listed above are also used to formulate the data in Table 10 .

From the above data, we can conclude that, currently, the State Committee on Statistics of the Republic of Uzbekistan has a database on tourism statistics, which is regularly formed and published in the prescribed manner. Today, it is advisable to improve the database used in the formation of tables of the tourism satellite account in tourism statistics in the following areas:

- reconciliation of data collected by the methods described above;

- to make changes and additions to the State statistical reports reflecting the indicators of the tourism industry, in connection with ensuring the coverage of the missing indicators;

- further enhancing the comparative analysis of tourism satellite account data with corresponding balance of payments data;

- logical-comparative analysis of data "Survey of domestic tourism and physical activity of the population";

- electronic data collection on "Survey of domestic tourism and physical activity of the population";

- ensuring the adequacy of tourism statistics in terms of production and consumption;

- formation of tourism aggregate indicators of tourism statistics by region of data sources;

- formation of quarterly aggregates of tourism as a source of data for tourism statistics. 


\section{REFERENCE LIST}

1. Law No. 549 of the Republic of Uzbekistan "On Tourism" adopted on July 18, 2019.

2. Popkov V.P., Kol O.D., Anokhina E.M. Monitoring of tourist business in a large city: theory and practice / St. Petersburg $2009.9 p$.

3. Statistical Office of the European Communities. Community Methodology on Tourism Statistics (Luxembourg, 1998).

4. Eurostat, European Implementation Manual on Tourism Satellite Accounts (Luxembourg 2000).

5. Commission of the European Communities. Organization for Economic Cooperation and Development, World Tourism Organization, United Nations. Tourism Satellite Account: Recommended Methodological Framework 2008 (Luxembourg, Madrid, New York, Paris, 2008).

6. Commission of the European Communities. Organization for Economic Cooperation and Development, World Tourism Organization, United Nations. International Recommendations for Tourism Statistics 2008.

7. "Methodological regulation on tourism statistics", Resolution \#47 of the State Statistics Committee of the Republic of Uzbekistan dated December 3, 2020.

8. "Methodological regulations on the formation of a tourism satellite account", approved by the Resolution \#41 of the State Statistics Committee dated September 30, 2019.

9. Mamadjanov A. "“Formation of a database of satellite accounts in tourism statistics", Institute for Personnel Training and Statistical Research under the State Statistics Committee of the Republic of Uzbekistan. "Materials of the Republican scientificpractical conference "Enhancing the role of modern information and communication technologies in the collection, processing and dissemination of statistical data." T: 2020. Pages 177-181. 